\title{
D-Optimal Split-plot Designs With Random Whole Plot Factor and Fixed Sub-plot Factor
}

\author{
Oluwole A Nuga ${ }^{1}$, Abba Zakirai Abdulhamid ${ }^{2}$, Shobanke Emmanuel Omobola Kayode ${ }^{3}$ \\ ${ }^{1}$ Department of Physical Sciences, Bells University of Technology, Ota, Nigeria \\ ${ }^{2}$ Department of Physical Sciences, Bells University of Technology, Ota, Nigeria \\ ${ }^{3}$ Department of Mathematics and Statistics, Federal Polytechnic Ilaro, Nigeria \\ Correspondence: Oluwole A Nuga, Department of Physical Sciences, Bells University of Technology, Nigeria
}

Received: August 17, $2021 \quad$ Accepted: November 29, $2021 \quad$ Online Published: December 21, 2021

doi:10.5539/ijsp.v11n1p1 URL: https://doi.org/10.5539/ijsp.v11n1p1

\begin{abstract}
This study examines design preference in Completely Randomized (CR) split-plot experiments involving random whole plot factor effect and fixed sub-plot factor effect. Many previous works on optimally designing split-plot experiments assumed only factors with fixed levels. However, the cases where interests are on random factors have received little attention. These problems have similarities with optimal design of experiments for fixed parameters of non-linear models because the solution rely on the unknown parameters. Design Space (DS) containing exhaustive list of balanced designs for a fixed sample size were compared for optimality using the product of determinants of derived information matrices of the Maximum Likelihood (ML) estimators equivalent to random and fixed effect in the model. Different magnitudes of components of variance configurations where variances of factor effects are larger than variances of error term were empirically used for the comparisons. The results revealed that the D-optimal designs are those with whole plot factor levels greater than replicates within each level of whole plot.
\end{abstract}

Keywords: whole plot, sub-plot, information matrices, D-optimal, variance component

\section{Introduction}

\subsection{Introduce the Problem}

Split-plot designs are applied when there is restricted randomization of the factor-levels of whole-plots. Whole-plot factors are usually called hard-to-change factors because their levels are not retuned independently for each experimental run (restricted randomization of factor levels). The sub-plot factor levels are referred to as easy-to-change factors because there is no such restriction of factor levels. The simplicity in the manner in which split-plot experiments are set-up has made it an experiment of choice in the industry. Many industrial experiments include hard-to-change factors in which funds and time are scarce (Goos and Vanderbroek 2001). Many authors have written articles devoted to the application of these designs in industrial experiments, some of them are Cornell (1988), Letsinger et.al. (1996), Bingham and Sitter (2001), and Trinca and Gilmour (2001). Computer procedures for constructing D-optimal split-plot design was given by Goos and Vanderbroek (2001, 2003). These algorithms are useful in several experimental situations that allow the combinations of factor levels. An algorithm which does not require allowable combinations of factor levels was proposed by Goos and Donev (2007). The algorithm requires specifying the type of factors, size of the whole-plot, size of the easy-to-change factor, ratio of error variances, model and starting design size. The constructions of these entire algorithms were based on the assumptions that factor levels are fixed. The part of the Fisher Information matrix for the estimation of the fixed parameters was used for the development of these procedures. Many works on optimal design in the fixed-effect study are based on the Fedorov algorithm (1972). A modification of the Fedorov procedure was employed by Goos and Vandebroek (2003) to construct optimal split-plot designs in the fixed-effect study. However, there is no unique approach for optimal designs in variance components models. As noted by Khuri (2000), the works on variance components analysis is fairly large but the quantity of articles dedicated to problems of designing experiment to estimate variance components is rather limited. Most of the works in this area of research were published in the sixties and seventies and were limited to some certain models. These problems have similarities with optimal experimental design for fixed parameters of non-linear models because the solution depends on the magnitude of unknown parameters. The solution also depends on the model and the method of estimation

Crump (1954) used the Analysis of Variance (ANOVA) estimation procedure to optimally design experiments for the 
one-way random model. Crump's result was later published by Anderson and Crump (1967). They showed that for a fixed number of experimental runs and a fixed number of levels of the random factor, the $\operatorname{Var}\left(\sigma_{\alpha}^{2}\right)$ and $\operatorname{Var}\left(\sigma_{\alpha}^{2} / \sigma_{e}^{2}\right)$ are minimized when there is an almost equal allocation of observation into each level of the random factor. The optimal number of levels of the random-effects depends on the true value of the variance components. Thompson \& Anderson (1975) used the truncated analysis of variance, Maximum Likelihood (ML) and modified ML estimators to re-examined the optimal designs proposed by Anderson \& Crump. The design criterion employed was the mean squared error for both balanced and unbalanced situations. The results revealed that for balanced design, modified ML estimator was superior as the optimal design was less sensitive to the interclass correlation $\rho=\sigma_{\alpha}^{2} /\left(\sigma_{\alpha}^{2}+\sigma_{e}^{2}\right)$ when $\rho<0.5$. Herrendofer (1979) constructed A-optimal designs of the ANOVA estimator for the one-way random model; he showed that for a fixed number of runs and a fixed number of levels of the random factor, designs with equal class frequencies is A-optimal. Other authors that have published work on optimal designs for the one-way random model include Murkerjee and Huda (1988), Giovagnoli and Sebastiani (1989, 1990). Norell (2006)

Gaylor (1960) constructed optimal designs in a two-way cross classification random model using the fitting constant method of estimation for the unbalanced data. Muse \& Anderson (1978) compared quite a few designs for the two-way crossed classification random model without interaction using both small-sample and asymptotic ML results. It was found that the optimum selection depends on the ratio of the main effect variance to the error variance. Shen et al. (1996) compared a number of balanced and unbalanced two-way designs for estimation of genetic parameters using simulated and asymptotic variances of the ML estimates. Recently, Loeza and Donev (2014) provided a general algorithm for constructing A-optimal and D-optimal balanced designs in a two-way crossed classification model without interaction. There are also published works on the two-way nested classification random model, such as Delgado and Iyer (1999), who developed an algorithm to construct locally optimum design for a two-way nested model. Also, Loeza and Donev (2014) developed a general algorithm for constructing locally A-optimal and D-optimal balanced designs. Nuga et al. (2014), proposed an algorithm that assumes a random effect model for a completely randomized split-plot design, the estimation method they consider was the Maximum Likelihood Estimator. Nuga et al (2017) extended the work by constructing D-optimal design for the same model using the restricted maximum likelihood. For both works only the part of the fisher information matrix corresponding to the estimation of the random parameters was used.

This present work examined the choice of designs for estimating a random hard-to-change factor or whole-plot factor and a fixed easy-to-change factor or sub-plot factor in a balanced completely randomized split-plot design. The main aim is to identify the structure of the completely randomized design that will maximize the product of determinants of the Fisher Information matrices corresponding to the fixed and random part of the model. Consider an experiment described by Stone and Sidel (2004) to investigate the effect of different varieties of wheat (plants) on the sensorial quality of product (bread) produced. This type of experiment can be conducted at two levels of randomization. The first level involves the randomization of varieties to samples, while the second level is the randomization of judges/panelist to divided samples. The samples are the whole-plots while the variety is the whole-plot factor effect. Judges are the sub-plot factor effects whereas the divided samples are the sub-plots. If the varieties are selected from population of wheat varieties and the interest is to estimate the variation within this population and panelist are specific panelist of interest whereby the effect on judges are assumed fixed.

The description of this split-plot model, the structure of the dispersion matrix and the derivation of the information matrices of the Maximum Likelihood (ML) estimator are given in details in the next section. In section 3, the work described procedures for generating exhaustive group of balanced designs corresponding to a fixed whole-plots size and sub-plot factor levels. Generated designs are compared in section 4 for D-optimality.

\section{Method}

\subsection{Completely Randomized Split-plot Designs}

Completely randomized split-plot designs involve randomizing levels of whole-plot factor to whole-plots arranged in completely randomized design and then randomizing levels of sub-plot factor to sub-plots within each whole-plot. The model equation for this work is

$$
\begin{aligned}
y_{i j k} & =\mu+\alpha_{i}+\beta_{j}+(\alpha \beta)_{i j}+\gamma_{i k}+e_{i j k} \\
i & =1,2, \ldots, v, j=1,2, \ldots, s, k=1,2, \ldots, r
\end{aligned}
$$

Where $\mathrm{v}$ is number of whole-plot factor level,

$s$ is number of sub-plot factor level

$r$ is number of replicates of whole-plot within each factor level.

For the completely randomized split-plot design, the size or number of whole-plots $(\mathrm{R})$ is given as. $R=V r$ 
$y_{i j k}$ is the dependent variable at the $k^{\text {th }}$ replicate in the $i^{\text {th }}$ level of whole-plot factor and the $j^{\text {th }}$ replicate of sub-plot factor, $\mu$ is the constant, $\alpha_{i}$ is the effect of the $i^{\text {th }}$ level of random whole-plot factor $\beta_{j}$ is effect of the $j^{t h}$ replicate of the fixed sub-plot factor. $(\alpha \beta)_{i j}$ is the interaction effect. $\gamma_{i k}$ is the whole-plot error term, $e_{i j k}$ is the sub-plot error term

\subsection{Matrix Formulation for the Model}

The matrix formulation of equation (1) to reflect response generated from the experimental set-up with a random whole-plot factor and fixed sub-plot factor is

$$
Y 1_{N}=\mu 1_{N}+X \beta+Z_{3} \alpha+Z_{2} \alpha \beta+Z_{1} \gamma+Z_{0} e
$$

$\mathrm{Y}$ is Nx1 vector of observations, $\mu$ is the general mean, $\mathrm{X}$ is the model matrix for the sub-plot fixed effect and $\mathrm{Z}$ 's are the indicator matrices for the random effects, here

$$
\text { Here, } \alpha=\left[\begin{array}{l}
\alpha_{1} \\
\cdot \\
\alpha_{v}
\end{array}\right], \beta=\left[\begin{array}{l}
\beta_{1} \\
\beta_{S}
\end{array}\right], \alpha \beta=\left[\begin{array}{l}
\alpha_{1} \beta_{1} \\
\alpha_{v} \beta_{S}
\end{array}\right], \gamma=\left[\begin{array}{l}
\gamma_{1} \\
\cdot \\
\gamma_{R}
\end{array}\right], \quad e=\left[\begin{array}{l}
e_{1} \\
e_{N}
\end{array}\right]
$$

The dispersion matrix is given as

$$
V(y)=V=\sum_{i=0}^{3} \sigma_{i}^{2} Z_{i} Z_{j}^{\prime} 3
$$

It is assumed that the expected values of the random effects are zero and the covariance as follows

$\operatorname{cov}\left(\alpha_{i}\right)=\sigma_{\alpha}^{2} I_{\alpha}, \operatorname{cov}(\alpha \beta)_{i j}=\sigma_{\alpha \beta}^{2} I_{\alpha \beta}, \operatorname{cov}\left(\gamma_{i k}\right)=\sigma_{\gamma}^{2} I_{R}, \operatorname{cov}(e)=\sigma_{e}^{2} I_{N}$

Where, $\sigma_{\alpha}^{2}, \sigma_{\alpha \beta}^{2}, \sigma_{\gamma}^{2}$ and $\sigma_{e}^{2}$ the variances of factor effects and error respectively.

\subsection{Fisher Information Matrices of the ML Estimators}

This split-plot model requires the derivation of two information matrices, the first one for the part of the model corresponding to the fixed parameter and the other to the variance components, the derivation begins with information matrix for the fixed parameter $\beta$.

From the general one given by Searle (1992), the Fisher-information matrix of the ML estimators for the fixed parameters is

For this model, $\mathrm{X}$ is defined in (6)

$$
F I_{m l}[\beta]=X V^{-1} X
$$

$$
X=1_{v} \otimes I_{s} \otimes 1_{r} \otimes 1_{n}
$$

Where $I_{S}$ is an Identity matrix of order

$1_{v}, 1_{r}$ and $1_{n}$ are column vectors (with all the elements as one) of order $v, s$ and $r$ respectively.

The inverse of the dispersion matrix $\left(V^{-1}\right)$ is obtained by firstly deriving the one for the full random model and then redefining the eigen values.

The $V^{-1}$ for the full random model as derived by Nuga et al. $(2014,2017)$ with the eigen values $\theta^{\prime} s$ now redefined as shown below in equation 7

$$
\begin{aligned}
& V^{-1}=\left(I_{v} \otimes I_{s} \otimes I_{r} \otimes C_{n}\right) \theta_{0}^{-1}+\left(I_{v} \otimes \bar{J}_{s} \otimes C_{r} \otimes \bar{J}_{n}\right) \theta_{1}^{-1}+\left(C_{v} \otimes C_{s} \otimes \bar{J}_{r} \otimes \bar{J}_{n}\right) \theta_{2}^{-1} \\
& +\left(\overline{J_{v}} \otimes C_{s} \otimes \bar{J}_{r} \otimes \bar{J}_{n}\right) \theta_{3}^{-1}+\left(C_{v} \otimes \bar{J}_{s} \otimes \overline{J_{r}} \otimes \bar{J}_{n}\right) \theta_{4}^{-1}+\left(\overline{J_{v}} \otimes \bar{J}_{s} \otimes \overline{J_{r}} \otimes \bar{J}_{n}\right) \theta_{5}^{-1}
\end{aligned}
$$

where,

$$
\begin{aligned}
& \theta_{0}=\sigma_{e}^{2}, \\
& \theta_{1}=\sigma_{e}^{2}+s n \sigma_{\gamma}^{2} \\
& \theta_{2}=\theta_{3}=\sigma_{e}^{2}+r n \sigma_{\alpha \beta}^{2} \\
& \theta_{4}=\sigma_{e}^{2}+s n \sigma_{\gamma}^{2}+r n \sigma_{\alpha \beta}^{2}+s r n \sigma_{\alpha}^{2} \\
& \theta_{5}=\sigma_{e}^{2}+b n \sigma_{\gamma}^{2}+r n \sigma_{\alpha \beta}^{2}+s r n \sigma_{\alpha}^{2}
\end{aligned}
$$

The matrix notations used in equation (7) are defined below as 
$\overline{J_{v}}=\frac{1}{v} J_{v}, \quad \bar{J}_{s}=\frac{1}{s} J_{s}, \quad \overline{J_{r}}=\frac{1}{r} J_{r} \quad$ and $\quad \overline{J_{n}}=\frac{1}{n} J_{n}$.

$C_{v}=I_{v}-\bar{J}_{v}, \quad C_{s}=I_{s}-\bar{J}_{s}, \quad C_{r}=I_{r}-\bar{J}_{r}$ and $\quad C_{n}=I_{n}-\overline{J_{n}}$

$J_{v}, J_{s}, J_{r}$ and $J_{n}$ square matrix (with all the elements as one) of order $v, s \quad r$ and $n$ respectively.

$C_{v}, C_{s}, C_{r}$ and $C_{n}$ are the centering matrices of order $v, s \quad r$ and $n$ respectively.

Multiplying equation 5, we have

$$
\begin{aligned}
& X^{\prime} V^{-1} X=\left(1_{v}^{\prime} \otimes I_{s} \otimes 1_{r}^{\prime} \otimes 1_{n}^{\prime}\right) V^{-1} X \\
& =\theta_{3}^{-1}\left(v \otimes C_{s} \otimes r \otimes n\right)+\theta_{5}^{-1}\left(v \otimes J_{s} \otimes r \otimes n\right)
\end{aligned}
$$

$$
X^{\iota} V^{=1} X=\operatorname{vrn}\left[\frac{C_{s}}{\theta_{3}}+\frac{\overline{J_{s}}}{\theta_{5}}\right]
$$

For the random part of the model, the general expression of the Fisher-Information matrix given by Searle (1992)

$$
\frac{1}{2}\left\{\operatorname{tr}\left\{V^{-1} Z_{i} Z_{i}^{\prime} V^{-1} Z_{j} Z_{j}^{\prime}\right\}_{i, j=0 \ldots . .3}\right\}=\frac{1}{2}\left\{S S\left\{Z_{i}^{\prime} V^{-1} Z_{j}\right\}_{i, j=0 \ldots 3}\right\}
$$

Where for example

$S S(A)$ : Sum of squares for component of matrix $A=\left\{a_{i j}\right\}: i, j=0 \ldots \ldots b$

$\operatorname{tr}(A)$ : Trace of the elements of matrix $\mathrm{A}$

The Fisher-information matrix of the ML estimators for the random part of the model is obtained by writing (9) explicitly as

$$
\text { . } \frac{1}{2} S S\left(\begin{array}{cccc}
Z_{0}^{\prime} V^{-1} Z_{0} & Z_{0}^{\prime} V^{-1} Z_{1} & Z_{0}^{\prime} V^{-1} Z_{2} & Z_{0}^{\prime} V^{-1} Z_{3} \\
Z_{1}^{\prime} V^{-1} Z_{0} & Z_{1}^{\prime} V^{-1} Z_{1} & Z_{1}^{\prime} V^{-1} Z_{2} & Z_{1}^{\prime} V^{-1} Z_{3} \\
Z_{2}^{\prime} V^{-1} Z_{0} & Z_{2}^{\prime} V^{-1} Z & Z_{2}^{\prime} V^{-1} Z_{2} & Z_{2}^{\prime} V^{-1} Z_{3} \\
Z_{3}^{\prime} V^{-1} Z_{0} & Z_{3}^{\prime} V^{-1} Z_{1} & Z_{3}^{\prime} V^{-1} Z_{2} & Z_{3}^{\prime} V^{-1} Z_{3}
\end{array}\right)
$$

Solving equation 11 , this becomes

$$
=\frac{1}{2}\left[\begin{array}{cccc}
t_{e e} & t_{\gamma \gamma} / s n & t_{\alpha \beta} / r n & t_{\alpha \alpha} / s r n \\
t_{\gamma \gamma} / s n & t_{\gamma \gamma} & t_{\alpha \alpha} / s r & t_{\alpha \alpha} / r \\
t_{\alpha \beta} / r n & t_{\alpha \alpha} / s r & t_{\alpha \beta} & t_{\alpha \alpha} / s \\
t_{\alpha \alpha} / s r n & t_{\alpha \alpha} / r & t_{\alpha \alpha} / s & t_{\alpha \alpha}
\end{array}\right]
$$

where,

$$
\begin{array}{cc}
t_{e e}=\left(\frac{v_{e}}{\theta_{0}^{2}}+\frac{v_{\gamma}}{\theta_{1}^{2}} \frac{t_{\alpha \beta}}{(r n)^{2}}\right), & t_{\alpha \alpha}=(s r n)^{2}\left(\frac{v_{\alpha}}{\theta_{4}^{2}}+\frac{1}{\theta_{5}^{2}}\right), \\
t_{\alpha \beta}=(r n)^{2}\left(\frac{v_{\varepsilon \beta}}{\theta_{2}^{2}}+\frac{v_{\beta}}{\theta_{2}^{2}} \frac{v_{\alpha}}{\theta_{4}^{2}}+\frac{1}{\theta_{5}^{2}}\right), & t_{\gamma \gamma}=(s n)^{2}\left(\frac{v_{\gamma}}{\theta_{1}^{2}}+\frac{v_{\alpha}}{\theta_{4}^{2}}+\frac{1}{\theta_{5}^{2}}\right)
\end{array}
$$

and

$$
v_{e}=v(s-1)(r-1), v_{\gamma}=v(s-1), v_{\alpha \beta}=(v-1)(s-1), v_{\beta}=s-1, v_{\alpha}=v-1
$$

The work is aimed at identify designs that optimizes product of the determinant of (8) and (11)

\subsection{Design Space Formulation}

Loeza and Donev (2014) described construction procedures for balanced A-optimal and D-optimal designs for the two-way crossed and nested classification random models. Nuga et al $(2014,2017)$ modified this approach using a random effect split-plot model This work further modified the approach to a design with a random whole plot factor and a fixed sub-plot factor. The procedure is described in this section

To generate Design Space (DS) of balanced design for the same number of sample size, the following steps are used.

- The sizes of whole plot $(R)$ that corresponds to any given sample size $(N)$ are non-prime numbers that are factors of $N$ and within the interval $4 \leq R \leq N / 2$. 
- The number of sub-plot factor level $(s)$ is obtained by the dividing $N$ with each $R$ i.e. $s=\frac{N}{R}$

- To obtain the whole plot factor level $(v)$ and the number of replicates within each level $(r)$ we recognize that the least number possible is two, i.e., two levels of the whole-plot factor and two whole-plots within each of these levels. Each $R$ is decomposed into its entire possible divisor.

- The permutations of each divisor are performed to obtain all possible CR designs and consequently all possible balance designs for any $N$

\subsection{Design Space Classification}

The DS generated in the last sub-section for $\mathrm{N}=24,36$, are classified into designs with the same number of whole-plots. Generated designs are also classified based on the structure of the CR design. Designs in which the number of whole plot factor levels are at least as large as replicates of whole-plots i.e., $\boldsymbol{v} \geq \boldsymbol{r}$ are in Group A, while designs in which the number of whole-plot factor levels is smaller than replicates of whole-plots i.e., $\boldsymbol{v}<\boldsymbol{r}$ are in Group B.

The DS from $\mathrm{N}=24$ and 36 contained 9 and 12 candidate designs respectively, the designs are listed below together with the class of designs in table 1.

Table 1. Design Space for $\mathrm{N}=24$ and $\mathrm{N}=36$

\begin{tabular}{|l|l|l|l|l|l|}
\hline $\begin{array}{l}\text { No of } \\
\text { Whole- } \\
\text { plot (R) }\end{array}$ & $\begin{array}{l}\text { Candidates } \\
\text { Designs N=36 }\end{array}$ & $\begin{array}{l}\text { Class of } \\
\text { Designs }\end{array}$ & $\begin{array}{l}\text { No of } \\
\text { Whole- } \\
\text { plot (R) }\end{array}$ & $\begin{array}{l}\text { Candidates } \\
\text { Designs N=24 }\end{array}$ & $\begin{array}{l}\text { Class of } \\
\text { Designs }\end{array}$ \\
\hline 4 & $\mathrm{v}=2, \mathrm{r}=2, \mathrm{~s}=9$ & A & 4 & $\mathrm{v}=2, \mathrm{r}=2, \mathrm{~s}=6$ & A \\
\hline 6 & $\mathrm{v}=3, \mathrm{r}=2, \mathrm{~s}=6$ & A & 6 & $\mathrm{v}=3, \mathrm{r}=2, \mathrm{~s}=4$ & A \\
\hline 6 & $\mathrm{v}=, 2 \mathrm{r}=3, \mathrm{~s}=6$ & $\mathrm{~B}$ & 6 & $\mathrm{v}=2, \mathrm{r}=3, \mathrm{~s}=4$ & $\mathrm{~B}$ \\
\hline 9 & $\mathrm{v}=3, \mathrm{r}=3, \mathrm{~s}=4$ & A & 8 & $\mathrm{v}=4, \mathrm{r}=2, \mathrm{~s}=3$ & A \\
\hline 12 & $\mathrm{v}=4, \mathrm{r}=3, \mathrm{~s}=3$ & A & 8 & $\mathrm{v}=2, \mathrm{r}=4, \mathrm{~s}=3$ & $\mathrm{~B}$ \\
\hline 12 & $\mathrm{v}=6, \mathrm{r}=2, \mathrm{~s}=3$ & A & 12 & $\mathrm{v}=4, \mathrm{r}=3, \mathrm{~s}=2$ & A \\
\hline 12 & $\mathrm{v}=2, \mathrm{r}=6, \mathrm{~s}=3$ & $\mathrm{~B}$ & 12 & $\mathrm{v}=6, \mathrm{r}=2, \mathrm{~s}=2$ & A \\
\hline 12 & $\mathrm{v}=3, \mathrm{r}=4, \mathrm{~s}=3$ & $\mathrm{~B}$ & 12 & $\mathrm{v}=3, \mathrm{r}=4, \mathrm{~s}=2$ & $\mathrm{~B}$ \\
\hline 18 & $\mathrm{v}=6, \mathrm{r}=3, \mathrm{~s}=2$ & A & 12 & $\mathrm{v}=2, \mathrm{r}=6, \mathrm{~s}=2$ & $\mathrm{~B}$ \\
\hline 18 & $\mathrm{v}=9, \mathrm{r}=2, \mathrm{~s}=2$ & A & & & \\
\hline 18 & $\mathrm{v}=3, \mathrm{r}=6, \mathrm{~s}=2$ & B & & & \\
\hline 18 & $\mathrm{v}=, 2 \mathrm{r}=9, \mathrm{~s}=2$ & B & & & \\
\hline
\end{tabular}

\subsection{Comparison and Optimality}

Designs with the same number of whole-plots will be compared in this section. The work compares designs from $R=6$ and 12 using the products of determinants of (8) and (10). The derived information matrices are functions of the unknown variances. Therefore, comparisons were done for prior proportional values of variance components. In many experimental situations, the factor variances are expected to be larger than the error variances. The whole plot error variance is also expected to be at least as large as the sub-plot error variance (Goos 2003) The work therefore compares designs with $\mathrm{R}=6$ and 12 from $\mathrm{N}=24$ and 36 based on some randomly selected values of variance components compatible with the two configurations shown below. The idea was to give different weights to the factor and interaction variances in other to test the robustness of the choice of optimal design to minimal and extreme differences

$$
\text { (i) } \sigma_{\alpha}^{2}>\sigma_{\alpha \beta}^{2}>\sigma_{\gamma}^{2} \geq \sigma_{e}^{2} \quad \text { (iv) } \sigma_{\alpha \beta}^{2}>\sigma_{\alpha}^{2}>\sigma_{\gamma}^{2} \geq \sigma_{e}^{2}
$$

\section{Results}

\subsection{Results for Configuration $\left(\sigma_{\alpha}^{2}>\sigma_{\alpha \beta}^{2}>\sigma_{\gamma}^{2} \geq \sigma_{e}^{2}\right)$}

In this sub-section, the work used the eight randomly selected values of variance components compatible with the first configuration to compare candidate designs from $(R, s)=(6,4),(6,6)$ and $(\mathrm{R}, \mathrm{s})=(12,2)$ and $(12,3)$. The first vector on table 2 assumes that $84 \%$ of the total variation in observation is accounted for by the variation in the whole-plot factor, while only $6 \%, 5 \%$ and $5 \%$ is accounted for by the interaction variance, the whole plot error variance and the sub-plot error variance respectively. The second vector assumes that $46 \%$ of the total variation in observation is accounted for by the whole plot factor variance while $44 \%, 5 \%$ and $5 \%$ is accounted for by the interaction variance, the whole plot error variance and the sub-plot error variance respectively. The remaining vectors specified on table 2 and table 3 are interpreted in the same way. Table 2 and table 3 show designs with the largest determinant (D-optimal) and the smallest determinant designs (Worst Designs) 
Table 2. Optimal Designs, Worst Designs and the Product of Determinant Using Selected Configuration

\begin{tabular}{|c|c|c|c|c|c|c|c|c|c|}
\hline \multicolumn{10}{|c|}{$\sigma_{\alpha}^{2}=8.4, \sigma_{\alpha \beta}^{2}=0.6, \sigma_{\gamma}^{2}=0.5, \sigma_{e}^{2}=0.5$} \\
\hline $\begin{array}{l}(\mathrm{R}, \mathrm{s}) \\
\text { Sample } \\
\text { Sizes }\end{array}$ & $\begin{array}{l}\text { Optimal } \\
\text { Designs }\end{array}$ & $\begin{array}{l}\text { Product } \\
\text { of DET }\end{array}$ & $\begin{array}{l}\text { Worst } \\
\text { Design }\end{array}$ & $\begin{array}{l}\text { Product } \\
\text { of DET }\end{array}$ & $(\mathrm{R}, \mathrm{s})$ & $\begin{array}{l}\text { Optimal } \\
\text { Designs }\end{array}$ & $\begin{array}{l}\text { Product } \\
\text { of DET }\end{array}$ & $\begin{array}{l}\text { Worst } \\
\text { Designs }\end{array}$ & $\begin{array}{l}\text { Product } \\
\text { of DET }\end{array}$ \\
\hline $\mathrm{R}=6, \mathrm{~s}=4$ & $\mathrm{v}=3, \mathrm{r}=2$ & 709.8 & $\mathrm{v}=2, \mathrm{r}=3$ & 213.1 & $\mathrm{R}=12, \mathrm{~s}=2$ & $\mathrm{v}=6, \mathrm{r}=2$ & 24.0 & $\mathrm{v}=2, \mathrm{r}=6$ & 271.4 \\
\hline $\mathrm{R}=6, \mathrm{~s}=6$ & $\mathrm{v}=3, \mathrm{r}=2$ & 28720 & $\mathrm{v}=2, \mathrm{r}=3$ & 4707 & $\mathrm{R}=12, \mathrm{~s}=3$ & $\mathrm{v}=6, \mathrm{r}=2$ & 9907 & $\mathrm{v}=2, \mathrm{r}=6$ & 363.3 \\
\hline \multicolumn{10}{|c|}{$\sigma_{\alpha}^{2}=4.6, \sigma_{\alpha \beta}^{2}=4.4, \sigma_{\gamma}^{2}=0.5, \sigma_{e}^{2}=0.5$} \\
\hline $\begin{array}{l}(\mathrm{R}, \mathrm{s}) \\
\text { Sample } \\
\text { Sizes }\end{array}$ & $\begin{array}{l}\text { Optimal } \\
\text { Designs }\end{array}$ & $\begin{array}{l}\text { Product } \\
\text { of DET }\end{array}$ & $\begin{array}{l}\text { Worst } \\
\text { Design }\end{array}$ & $\begin{array}{l}\text { Product } \\
\text { of DET }\end{array}$ & $(\mathrm{R}, \mathrm{s})$ & $\begin{array}{l}\text { Optimal } \\
\text { Designs }\end{array}$ & $\begin{array}{l}\text { Product } \\
\text { of DET }\end{array}$ & $\begin{array}{l}\text { Worst } \\
\text { Design }\end{array}$ & $\begin{array}{l}\text { Product } \\
\text { of DET }\end{array}$ \\
\hline $\mathrm{R}=6, \mathrm{~s}=4$ & $\mathrm{v}=3, \mathrm{r}=2$ & 0.16 & $\mathrm{v}=2, \mathrm{r}=3$ & 0.03 & $\mathrm{R}=12, \mathrm{~s}=2$ & $\mathrm{v}=6, \mathrm{r}=2$ & 1.01 & $\mathrm{v}=2, \mathrm{r}=6$ & 0.05 \\
\hline $\mathrm{R}=6, \mathrm{~s}=6$ & $\mathrm{v}=3, \mathrm{r}=2$ & 0.28 & $\mathrm{v}=2, \mathrm{r}=3$ & 0.024 & $\mathrm{R}=12, \mathrm{~s}=3$ & $\mathrm{v}=6, \mathrm{r}=2$ & 9.68 & $\mathrm{v}=2, \mathrm{r}=6$ & 0.15 \\
\hline \multicolumn{10}{|c|}{$\sigma_{\alpha}^{2}=7.4, \sigma_{\alpha \beta}^{2}=1.1, \sigma_{\gamma}^{2}=1, \sigma_{e}^{2}=0.5$} \\
\hline $\begin{array}{l}\text { R,s }) \\
\text { Sample } \\
\text { Sizes }\end{array}$ & $\begin{array}{l}\text { Optimal } \\
\text { Designs }\end{array}$ & $\begin{array}{l}\text { Product } \\
\text { of DET }\end{array}$ & $\begin{array}{l}\text { Worst } \\
\text { Design }\end{array}$ & $\begin{array}{l}\text { Product } \\
\text { of DET }\end{array}$ & $(\mathrm{R}, \mathrm{s})$ & $\begin{array}{l}\text { Optimal } \\
\text { Designs }\end{array}$ & $\begin{array}{l}\text { Product } \\
\text { of DET }\end{array}$ & $\begin{array}{l}\text { Worst } \\
\text { Design }\end{array}$ & $\begin{array}{l}\text { Product } \\
\text { of DET }\end{array}$ \\
\hline $\mathrm{R}=6, \mathrm{~s}=4$ & $\mathrm{v}=3, \mathrm{r}=2$ & 32.4 & $\mathrm{v}=2, \mathrm{r}=3$ & 8.46 & $\mathrm{R}=12, \mathrm{~s}=2$ & $\mathrm{v}=6, \mathrm{r}=2$ & 31.52 & $\mathrm{v}=2, \mathrm{r}=6$ & 2.36 \\
\hline $\mathrm{R}=6, \mathrm{~s}=6$ & $\mathrm{v}=3, \mathrm{r}=2$ & 514.9 & $\mathrm{v}=2, \mathrm{r}=3$ & 68.5 & $\mathrm{R}=12, \mathrm{~s}=3$ & $\mathrm{v}=6, \mathrm{r}=2$ & 719.8 & $\mathrm{v}=2, \mathrm{r}=6$ & 21 \\
\hline \multicolumn{10}{|c|}{$\sigma_{\alpha}^{2}=4.3, \sigma_{\alpha \beta}^{2}=4.2, \sigma_{\gamma}^{2}=1, \sigma_{e}^{2}=0.5$} \\
\hline $\begin{array}{l}(\mathrm{R}, \mathrm{s}) \\
\text { Sample } \\
\text { Sizes }\end{array}$ & $\begin{array}{l}\text { Optimal } \\
\text { Designs }\end{array}$ & $\begin{array}{l}\text { Product } \\
\text { of DET }\end{array}$ & $\begin{array}{l}\text { Worst } \\
\text { Design }\end{array}$ & $\begin{array}{l}\text { Product } \\
\text { of DET }\end{array}$ & $(\mathrm{R}, \mathrm{s})$ & $\begin{array}{l}\text { Optimal } \\
\text { Designs }\end{array}$ & $\begin{array}{l}\text { Product } \\
\text { of DET }\end{array}$ & $\begin{array}{l}\text { Worst } \\
\text { Design }\end{array}$ & $\begin{array}{l}\text { Product } \\
\text { of DET }\end{array}$ \\
\hline $\mathrm{R}=6, \mathrm{~s}=4$ & $\mathrm{v}=3, \mathrm{r}=2$ & 0.1 & $\mathrm{v}=2, \mathrm{r}=3$ & 0.02 & $\mathrm{R}=12, \mathrm{~s}=2$ & $\mathrm{v}=6, \mathrm{r}=2$ & 0.6 & $\mathrm{v}=2, \mathrm{r}=6$ & 0.034 \\
\hline $\mathrm{R}=6, \mathrm{~s}=6$ & $\mathrm{v}=3, \mathrm{r}=2$ & 0.18 & $\mathrm{v}=2, \mathrm{r}=3$ & 0.002 & $\mathrm{R}=12, \mathrm{~s}=3$ & $\mathrm{v}=6, \mathrm{r}=2$ & 6.29 & $\mathrm{v}=2, \mathrm{r}=6$ & 0.11 \\
\hline
\end{tabular}

Table 3. Optimal Designs, Worst Designs and the Product of Determinant Using Selected Configuration

\begin{tabular}{|c|c|c|c|c|c|c|c|c|c|}
\hline \multicolumn{10}{|c|}{$\sigma_{\alpha}^{2}=3.6, \sigma_{\alpha \beta}^{2}=3.4, \sigma_{\gamma}^{2}=1.5, \sigma_{e}^{2}=1.5$} \\
\hline $\begin{array}{l}(\mathrm{R}, \quad \mathrm{s}) \\
\text { Sample } \\
\text { Sizes }\end{array}$ & $\begin{array}{l}\text { Optimal } \\
\text { Designs }\end{array}$ & $\begin{array}{l}\text { Product } \\
\text { of DET }\end{array}$ & $\begin{array}{l}\text { Worst } \\
\text { Design }\end{array}$ & $\begin{array}{l}\text { Product } \\
\text { of DET }\end{array}$ & $(\mathrm{R}, \mathrm{s})$ & $\begin{array}{l}\text { Optimal } \\
\text { Designs }\end{array}$ & $\begin{array}{l}\text { Product } \\
\text { of DET }\end{array}$ & $\begin{array}{l}\text { Worst } \\
\text { Designs }\end{array}$ & $\begin{array}{l}\text { Product } \\
\text { of DET }\end{array}$ \\
\hline $\mathrm{R}=6, \mathrm{~s}=4$ & $\mathrm{v}=3, \mathrm{r}=2$ & 0.008 & $\mathrm{v}=2, \mathrm{r}=3$ & 0.002 & $\mathrm{R}=12, \mathrm{~s}=2$ & $\mathrm{v}=6, \mathrm{r}=2$ & 0.05 & $\mathrm{v}=2, \mathrm{r}=6$ & 0.005 \\
\hline $\mathrm{R}=6, \mathrm{~s}=6$ & $\mathrm{v}=3, \mathrm{r}=2$ & 0.02 & $\mathrm{v}=2, \mathrm{r}=3$ & 0.002 & $\mathrm{R}=12, \mathrm{~s}=3$ & $\mathrm{v}=6, \mathrm{r}=2$ & 0.45 & $\mathrm{v}=2, \mathrm{r}=6$ & 0.01 \\
\hline \multicolumn{10}{|c|}{$\sigma_{\alpha}^{2}=5.4, \sigma_{\alpha \beta}^{2}=1.6, \sigma_{\gamma}^{2}=1.5, \sigma_{e}^{2}=1.5$} \\
\hline $\begin{array}{l}\text { R, s) } \\
\text { Sample } \\
\text { Sizes }\end{array}$ & $\begin{array}{l}\text { Optimal } \\
\text { Designs }\end{array}$ & $\begin{array}{l}\text { Product } \\
\text { of DET }\end{array}$ & $\begin{array}{l}\text { Worst } \\
\text { Design }\end{array}$ & $\begin{array}{l}\text { Product } \\
\text { of DET }\end{array}$ & $(\mathrm{R}, \mathrm{s})$ & $\begin{array}{l}\text { Optimal } \\
\text { Designs }\end{array}$ & $\begin{array}{l}\text { Product } \\
\text { of DET }\end{array}$ & $\begin{array}{l}\text { Worst } \\
\text { Design }\end{array}$ & $\begin{array}{l}\text { Product } \\
\text { of DET }\end{array}$ \\
\hline $\mathrm{R}=6, \mathrm{~s}=4$ & $\mathrm{v}=3, \mathrm{r}=2$ & 0.1 & $\mathrm{v}=2, \mathrm{r}=3$ & 0.03 & $\mathrm{R}=12, \mathrm{~s}=2$ & $\mathrm{v}=6, \mathrm{r}=2$ & 0.03 & $\mathrm{v}=2, \mathrm{r}=6$ & 0.27 \\
\hline $\mathrm{R}=6, \mathrm{~s}=6$ & $\mathrm{v}=3, \mathrm{r}=2$ & 0.53 & $\mathrm{v}=2, \mathrm{r}=3$ & 0.01 & $\mathrm{R}=12, \mathrm{~s}=3$ & $\mathrm{v}=6, \mathrm{r}=2$ & 3,59 & $\mathrm{v}=2, \mathrm{r}=6$ & 0.17 \\
\hline \multicolumn{10}{|c|}{$\sigma_{\alpha}^{2}=4.4, \sigma_{\alpha \beta}^{2}=2.1, \sigma_{\gamma}^{2}=2, \sigma_{e}^{2}=1.5$} \\
\hline $\begin{array}{l}(\mathrm{R}, \mathrm{s}) \\
\text { Sample } \\
\text { Sizes }\end{array}$ & $\begin{array}{l}\text { Optimal } \\
\text { Designs }\end{array}$ & $\begin{array}{l}\text { Product } \\
\text { of DET }\end{array}$ & $\begin{array}{l}\text { Worst } \\
\text { Design }\end{array}$ & $\begin{array}{l}\text { Product } \\
\text { of DET }\end{array}$ & $(\mathrm{R}, \mathrm{s})$ & $\begin{array}{l}\text { Optimal } \\
\text { Designs }\end{array}$ & $\begin{array}{l}\text { Product } \\
\text { of DET }\end{array}$ & $\begin{array}{l}\text { Worst } \\
\text { Design }\end{array}$ & $\begin{array}{l}\text { Product } \\
\text { of DET }\end{array}$ \\
\hline $\mathrm{R}=6, \mathrm{~s}=4$ & $\mathrm{v}=3, \mathrm{r}=2$ & 0.03 & $\mathrm{v}=2, \mathrm{r}=3$ & 0.01 & $\mathrm{R}=12, \mathrm{~s}=2$ & $\mathrm{v}=6, \mathrm{r}=2$ & & $\mathrm{v}=2, \mathrm{r}=6$ & \\
\hline $\mathrm{R}=6, \mathrm{~s}=6$ & $\mathrm{v}=3, \mathrm{r}=2$ & & $\mathrm{v}=2, \mathrm{r}=3$ & & $\mathrm{R}=12, \mathrm{~s}=3$ & $\mathrm{v}=6, \mathrm{r}=2$ & 1.38 & $\mathrm{v}=2, \mathrm{r}=6$ & 0.06 \\
\hline \multicolumn{10}{|c|}{$\sigma_{\alpha}^{2}=3.3, \sigma_{\alpha \beta}^{2}=2.2, \sigma_{\gamma}^{2}=2, \sigma_{e}^{2}=1.5$} \\
\hline $\begin{array}{l}(\mathrm{R}, \mathrm{s}) \\
\text { Sample } \\
\text { Sizes }\end{array}$ & $\begin{array}{l}\text { Optimal } \\
\text { Designs }\end{array}$ & $\begin{array}{l}\text { Product } \\
\text { of DET }\end{array}$ & $\begin{array}{l}\text { Worst } \\
\text { Design }\end{array}$ & $\begin{array}{l}\text { Product } \\
\text { of DET }\end{array}$ & $(\mathrm{R}, \mathrm{s})$ & $\begin{array}{l}\text { Optimal } \\
\text { Designs }\end{array}$ & $\begin{array}{l}\text { Product } \\
\text { of DET }\end{array}$ & $\begin{array}{l}\text { Worst } \\
\text { Design }\end{array}$ & $\begin{array}{l}\text { Product } \\
\text { of DET }\end{array}$ \\
\hline $\mathrm{R}=6, \mathrm{~s}=4$ & $\mathrm{v}=3, \mathrm{r}=2$ & 0.007 & $\mathrm{v}=2, \mathrm{r}=3$ & 0.002 & $\mathrm{R}=12, \mathrm{~s}=2$ & $\mathrm{v}=6, \mathrm{r}=2$ & 0.05 & $\mathrm{v}=2, \mathrm{r}=6$ & 0.004 \\
\hline $\mathrm{R}=6, \mathrm{~s}=6$ & $\mathrm{v}=3, \mathrm{r}=2$ & 0.02 & $\mathrm{v}=2, \mathrm{r}=3$ & 0.002 & $\mathrm{R}=12, \mathrm{~s}=3$ & $\mathrm{v}=6, \mathrm{r}=2$ & 0.43 & $\mathrm{v}=2, \mathrm{r}=6$ & 0.01 \\
\hline
\end{tabular}




\subsection{Results for Configuration $\left(\sigma_{\alpha \beta}^{2}>\sigma_{\alpha}^{2}>\sigma_{\gamma}^{2} \geq \sigma_{e}^{2}\right.$ )}

By interchanging the values of whole-plot variance with the values of the interaction variance used in the last sub-section, eight selected vectors of values of variance components compatible with second configuration were obtained and used to compare candidate designs from $(R, s)=(6,4),(6,6)$ and $(\mathrm{R}, \mathrm{s})=(12,2)$ and $(12,3)$. The first vector on table 4 assumes that $84 \%$ of the total variation in observation is accounted for by the interaction variance while only $6 \%, 5 \%$ and $5 \%$ is accounted for by the whole plot factor variance, the whole plot error variance and the sub-plot error variance respectively. Likewise, the second vector assumes that $46 \%$ of the total variation in observation is accounted for by the interaction variance, while $44 \%, 5 \%$ and $5 \%$ is accounted for by the whole plot factor variance, the whole plot error variance and the sub-plot error variance respectively. The remaining vectors specified on table 4 and table 5 are interpreted in the same way

Table 4 and table 5 show the D-optimal (largest determinant) designs with the product of its determinant, the worst designs (smallest determinant) designs with the product of its determinants for eight selected configurations

Table 4. Optimal Designs, Worst Designs and the Product of Determinant Using Selected Configuration

\begin{tabular}{|c|c|c|c|c|c|c|c|c|c|}
\hline \multicolumn{10}{|c|}{$\sigma_{\alpha}^{2}=0.6, \sigma_{\alpha \beta}^{2}=8.4, \sigma_{\gamma}^{2}=0.5, \sigma_{e}^{2}=0.5$} \\
\hline $\begin{array}{l}(\mathrm{R}, \mathrm{s}) \\
\text { Sample } \\
\text { Sizes }\end{array}$ & $\begin{array}{l}\text { Optimal } \\
\text { Designs }\end{array}$ & $\begin{array}{l}\text { Product } \\
\text { of DET }\end{array}$ & $\begin{array}{l}\text { Worst } \\
\text { Design }\end{array}$ & $\begin{array}{l}\text { Product } \\
\text { of DET }\end{array}$ & $(\mathrm{R}, \mathrm{s})$ & $\begin{array}{l}\text { Optimal } \\
\text { Designs }\end{array}$ & $\begin{array}{l}\text { Product } \\
\text { of DET }\end{array}$ & $\begin{array}{l}\text { Worst } \\
\text { Designs }\end{array}$ & $\begin{array}{l}\text { Product } \\
\text { of DET }\end{array}$ \\
\hline $\mathrm{R}=6, \mathrm{~s}=4$ & $\mathrm{v}=3, \mathrm{r}=2$ & 0.02 & $\mathrm{v}=2, \mathrm{r}=3$ & 0.003 & $\mathrm{R}=12, \mathrm{~s}=2$ & $\mathrm{v}=6, \mathrm{r}=2$ & 0.18 & $\mathrm{v}=2, \mathrm{r}=6$ & 0008 \\
\hline $\mathrm{R}=6, \mathrm{~s}=6$ & $\mathrm{v}=3, \mathrm{r}=2$ & 0.015 & $\mathrm{v}=2, \mathrm{r}=3$ & 0.001 & $\mathrm{R}=12, \mathrm{~s}=3$ & $\mathrm{v}=6, \mathrm{r}=2$ & 1.5 & $\mathrm{v}=2, \mathrm{r}=6$ & 0.02 \\
\hline \multicolumn{10}{|c|}{$\sigma_{\alpha}^{2}=4.4, \sigma_{\alpha \beta}^{2}=4.6, \sigma_{v}^{2}=0.5, \sigma_{e}^{2}=0.5$} \\
\hline $\begin{array}{l}(\mathrm{R}, \mathrm{s}) \\
\text { Sample } \\
\text { Sizes }\end{array}$ & $\begin{array}{l}\text { Optimal } \\
\text { Designs }\end{array}$ & $\begin{array}{l}\text { Product } \\
\text { of DET }\end{array}$ & $\begin{array}{l}\text { Worst } \\
\text { Design }\end{array}$ & $\begin{array}{l}\text { Product } \\
\text { of DET }\end{array}$ & $(\mathrm{R}, \mathrm{s})$ & $\begin{array}{l}\text { Optimal } \\
\text { Designs }\end{array}$ & $\begin{array}{l}\text { Product } \\
\text { of DET }\end{array}$ & $\begin{array}{l}\text { Worst } \\
\text { Design }\end{array}$ & $\begin{array}{l}\text { Product } \\
\text { of DET }\end{array}$ \\
\hline $\mathrm{R}=6, \mathrm{~s}=4$ & $\mathrm{v}=3, \mathrm{r}=2$ & 0.13 & $\mathrm{v}=2, \mathrm{r}=3$ & 0.02 & $\mathrm{R}=12, \mathrm{~s}=2$ & $\mathrm{v}=6, \mathrm{r}=2$ & 0.89 & $\mathrm{v}=2, \mathrm{r}=6$ & 0.04 \\
\hline $\mathrm{R}=6, \mathrm{~s}=6$ & $\mathrm{v}=3, \mathrm{r}=2$ & 0.22 & $\mathrm{v}=2, \mathrm{r}=3$ & 0.02 & $\mathrm{R}=12, \mathrm{~s}=3$ & $\mathrm{v}=6, \mathrm{r}=2$ & 8.29 & $\mathrm{v}=2, \mathrm{r}=6$ & 0.13 \\
\hline \multicolumn{10}{|c|}{$\sigma_{\alpha}^{2}=1.1, \sigma_{\alpha \beta}^{2}=7.4, \sigma_{v}^{2}=1, \sigma_{e}^{2}=0.5$} \\
\hline$(\mathrm{R}, \mathrm{s})$ & $\begin{array}{l}\text { Optimal } \\
\text { Designs }\end{array}$ & $\begin{array}{l}\text { Product } \\
\text { of DET }\end{array}$ & $\begin{array}{l}\text { Worst } \\
\text { Design }\end{array}$ & $\begin{array}{l}\text { Product } \\
\text { of DET }\end{array}$ & $(\mathrm{R}, \mathrm{s})$ & $\begin{array}{l}\text { Optimal } \\
\text { Designs }\end{array}$ & $\begin{array}{l}\text { Product } \\
\text { of DET }\end{array}$ & $\begin{array}{l}\text { Worst } \\
\text { Design }\end{array}$ & $\begin{array}{l}\text { Product } \\
\text { of DET }\end{array}$ \\
\hline $\mathrm{R}=6, \mathrm{~s}=4$ & $\mathrm{v}=3, \mathrm{r}=2$ & 0.01 & $\mathrm{v}=2, \mathrm{r}=3$ & 0.003 & $\mathrm{R}=12, \mathrm{~s}=2$ & $\mathrm{v}=6, \mathrm{r}=2$ & 0.15 & $\mathrm{v}=2, \mathrm{r}=6$ & 0.007 \\
\hline $\mathrm{R}=6, \mathrm{~s}=6$ & $\mathrm{v}=3, \mathrm{r}=2$ & 0.012 & $\mathrm{v}=2, \mathrm{r}=3$ & 0.001 & $\mathrm{R}=12, \mathrm{~s}=3$ & $\mathrm{v}=6, \mathrm{r}=2$ & 1.15 & $\mathrm{v}=2, \mathrm{r}=6$ & 0.02 \\
\hline \multicolumn{10}{|c|}{$\sigma_{\alpha}^{2}=4.2, \sigma_{\alpha \beta}^{2}=4.3, \sigma_{\gamma}^{2}=1, \sigma_{e}^{2}=0.5$} \\
\hline $\begin{array}{l}(\mathrm{R}, \mathrm{s}) \\
\text { Sample } \\
\text { Sizes }\end{array}$ & $\begin{array}{l}\text { Optimal } \\
\text { Designs }\end{array}$ & $\begin{array}{l}\text { Product } \\
\text { of DET }\end{array}$ & $\begin{array}{l}\text { Worst } \\
\text { Design }\end{array}$ & $\begin{array}{l}\text { Product } \\
\text { of DET }\end{array}$ & $(\mathrm{R}, \mathrm{s})$ & $\begin{array}{l}\text { Optimal } \\
\text { Designs }\end{array}$ & $\begin{array}{l}\text { Product } \\
\text { of DET }\end{array}$ & $\begin{array}{l}\text { Worst } \\
\text { Design }\end{array}$ & $\begin{array}{l}\text { Product } \\
\text { of DET }\end{array}$ \\
\hline $\mathrm{R}=6, \mathrm{~s}=4$ & $\mathrm{v}=3, \mathrm{r}=2$ & 0.09 & $\mathrm{v}=2, \mathrm{r}=3$ & 0.02 & $\mathrm{R}=12, \mathrm{~s}=2$ & $\mathrm{v}=6, \mathrm{r}=2$ & 0.03 & $\mathrm{v}=2, \mathrm{r}=6$ & 0.64 \\
\hline $\mathrm{R}=6, \mathrm{~s}=6$ & $\mathrm{v}=3, \mathrm{r}=2$ & 0.16 & $\mathrm{v}=2, \mathrm{r}=3$ & 0.02 & $\mathrm{R}=12, \mathrm{~s}=3$ & $\mathrm{v}=6, \mathrm{r}=2$ & 5.8 & $\mathrm{v}=2, \mathrm{r}=6$ & 0.1 \\
\hline
\end{tabular}

Table 5. Optimal Designs, Worst Designs and the Product of Determinant Using Selected Configuration

\begin{tabular}{|c|c|c|c|c|c|c|c|c|c|}
\hline \multicolumn{10}{|c|}{$\sigma_{\alpha}^{2}=3.4, \sigma_{\alpha \beta}^{2}=3.6, \sigma_{\gamma}^{2}=1.5, \sigma_{e}^{2}=1.5$} \\
\hline $\begin{array}{l}\text { Sample } \\
\text { Sizes } \\
(\mathrm{R}, \mathrm{s})\end{array}$ & $\begin{array}{l}\text { Optimal } \\
\text { Designs }\end{array}$ & $\begin{array}{l}\text { Product } \\
\text { of DET }\end{array}$ & $\begin{array}{l}\text { Worst } \\
\text { Design }\end{array}$ & D-value & $(\mathrm{R}, \mathrm{s})$ & $\begin{array}{l}\text { Optimal } \\
\text { Designs }\end{array}$ & $\begin{array}{l}\text { D- } \\
\text { value }\end{array}$ & $\begin{array}{l}\text { Worst } \\
\text { Designs }\end{array}$ & $\begin{array}{l}\text { Product } \\
\text { of DET }\end{array}$ \\
\hline $\mathrm{R}=6, \mathrm{~s}=4$ & $\mathrm{v}=3, \mathrm{r}=2$ & 0.008 & $\mathrm{v}=2, \mathrm{r}=3$ & 0.002 & $\mathrm{R}=12, \mathrm{~s}=2$ & $\mathrm{v}=6, \mathrm{r}=2$ & 0.04 & $\mathrm{v}=2, \mathrm{r}=6$ & 0.003 \\
\hline $\mathrm{R}=6, \mathrm{~s}=6$ & $\mathrm{v}=3, \mathrm{r}=2$ & 0.011 & $\mathrm{v}=2, \mathrm{r}=3$ & 0.001 & $\mathrm{R}=12, \mathrm{~s}=3$ & $\mathrm{v}=6, \mathrm{r}=2$ & 0.45 & $\mathrm{v}=2, \mathrm{r}=6$ & 0.01 \\
\hline \multicolumn{10}{|c|}{$\sigma_{\alpha}^{2}=1.6, \sigma_{\alpha \beta}^{2}=5.4, \sigma_{\gamma}^{2}=1.5, \sigma_{e}^{2}=1.5$} \\
\hline $\begin{array}{l}\text { Sample } \\
\text { Sizes } \\
(\mathrm{R}, \mathrm{s})\end{array}$ & $\begin{array}{l}\text { Optimal } \\
\text { Designs }\end{array}$ & $\begin{array}{l}\text { Product } \\
\text { of DET }\end{array}$ & $\begin{array}{l}\text { Worst } \\
\text { Design }\end{array}$ & $\begin{array}{l}\text { Product } \\
\text { of DET }\end{array}$ & $(\mathrm{R}, \mathrm{s})$ & $\begin{array}{l}\text { Optimal } \\
\text { Designs }\end{array}$ & $\begin{array}{l}\text { Product } \\
\text { of DET }\end{array}$ & $\begin{array}{l}\text { Worst } \\
\text { Design }\end{array}$ & $\begin{array}{l}\text { Product } \\
\text { of DET }\end{array}$ \\
\hline $\mathrm{R}=6, \mathrm{~s}=4$ & $\mathrm{v}=3, \mathrm{r}=2$ & 0.002 & $\mathrm{v}=2, \mathrm{r}=3$ & 0.001 & $\mathrm{R}=12, \mathrm{~s}=2$ & $\mathrm{v}=6, \mathrm{r}=2$ & 0.02 & $\mathrm{v}=2, \mathrm{r}=6$ & 0.001 \\
\hline $\mathrm{R}=6, \mathrm{~s}=6$ & $\mathrm{v}=3, \mathrm{r}=2$ & 0.002 & $\mathrm{v}=2, \mathrm{r}=3$ & 0.000 & $\mathrm{R}=12, \mathrm{~s}=3$ & $\mathrm{v}=6, \mathrm{r}=2$ & 0.13 & $\mathrm{v}=2, \mathrm{r}=6$ & 0.004 \\
\hline
\end{tabular}




\begin{tabular}{|c|c|c|c|c|c|c|c|c|c|}
\hline \multicolumn{10}{|c|}{$\sigma_{\alpha}^{2}=2.1, \sigma_{\alpha \beta}^{2}=4.4, \sigma_{\gamma}^{2}=2, \sigma_{e}^{2}=1.5$} \\
\hline $\begin{array}{l}\text { Sample } \\
\text { Sizes } \\
(\mathrm{R}, \mathrm{s})\end{array}$ & $\begin{array}{l}\text { Optimal } \\
\text { Designs }\end{array}$ & $\begin{array}{l}\text { Product } \\
\text { of DET }\end{array}$ & $\begin{array}{l}\text { Worst } \\
\text { Design }\end{array}$ & $\begin{array}{l}\text { Product } \\
\text { of DET }\end{array}$ & $(\mathrm{R}, \mathrm{s})$ & $\begin{array}{l}\text { Optimal } \\
\text { Designs }\end{array}$ & $\begin{array}{l}\text { Product } \\
\text { of DET }\end{array}$ & $\begin{array}{l}\text { Worst } \\
\text { Design }\end{array}$ & $\begin{array}{l}\text { Product } \\
\text { of DET }\end{array}$ \\
\hline $\mathrm{R}=6, \mathrm{~s}=4$ & $\mathrm{v}=3, \mathrm{r}=2$ & 0.002 & $\mathrm{v}=2, \mathrm{r}=3$ & 0.001 & $\mathrm{R}=12, \mathrm{~s}=2$ & $\mathrm{v}=6, \mathrm{r}=2$ & 0.12 & $\mathrm{v}=2, \mathrm{r}=6$ & 0.013 \\
\hline $\mathrm{R}=6, \mathrm{~s}=6$ & $\mathrm{v}=3, \mathrm{r}=2$ & 0.12 & $\mathrm{v}=2, \mathrm{r}=3$ & 0.02 & $\mathrm{R}=12, \mathrm{~s}=3$ & $\mathrm{v}=6, \mathrm{r}=2$ & 0.18 & $\mathrm{v}=2, \mathrm{r}=6$ & 0.01 \\
\hline \multicolumn{10}{|c|}{$\sigma_{\alpha}^{2}=3.2, \sigma_{\alpha \beta}^{2}=3.3, \sigma_{\gamma}^{2}=2, \sigma_{e}^{2}=1.5$} \\
\hline $\begin{array}{l}(\mathrm{R}, \mathrm{s}) \\
\text { Sample } \\
\text { Sizes }\end{array}$ & $\begin{array}{l}\text { Optimal } \\
\text { Designs }\end{array}$ & $\begin{array}{l}\text { Product } \\
\text { of DET }\end{array}$ & $\begin{array}{l}\text { Worst } \\
\text { Design }\end{array}$ & $\begin{array}{l}\text { Product } \\
\text { of DET }\end{array}$ & $(\mathrm{R}, \mathrm{s})$ & $\begin{array}{l}\text { Optimal } \\
\text { Designs }\end{array}$ & $\begin{array}{l}\text { Product } \\
\text { of DET }\end{array}$ & $\begin{array}{l}\text { Worst } \\
\text { Design }\end{array}$ & $\begin{array}{l}\text { Product } \\
\text { of DET }\end{array}$ \\
\hline $\mathrm{R}=6, \mathrm{~s}=4$ & $\mathrm{v}=3, \mathrm{r}=2$ & 0.01 & $\mathrm{v}=2, \mathrm{r}=3$ & 0.002 & $\mathrm{R}=12, \mathrm{~s}=2$ & $\mathrm{v}=6, \mathrm{r}=2$ & 0.04 & $\mathrm{v}=2, \mathrm{r}=6$ & 0.004 \\
\hline $\mathrm{R}=6, \mathrm{~s}=6$ & $\mathrm{v}=3, \mathrm{r}=2$ & 0.014 & $\mathrm{v}=2, \mathrm{r}=3$ & 0.002 & $\mathrm{R}=12, \mathrm{~s}=3$ & $\mathrm{v}=6, \mathrm{r}=2$ & 0.40 & $\mathrm{v}=2, \mathrm{r}=6$ & 0.01 \\
\hline
\end{tabular}

\section{Results Discussion}

The D-optimal designs and the smallest determinant designs (Worst Designs) are unchanged for all the sixteen vectors of values used in $(R, s)=(6,4),(6,6)$ and $(\mathrm{R}, \mathrm{s})=(12,2)$ and $(12,3)$. It is also observed from all the vector of values and sample sizes used that the D-optimal designs are designs in which the size of the whole-plot factor is larger than size of replication and the designs with the smallest determinant are the designs in which the size of the whole-plot factor are smaller than the size of replication. Which can be stated that CR design structure of D-optimal and D-worst designs were $v>r$ and $v<r$, respectively. The choice of optimal design is not affected by the size of the sub-plot factor.

Practically, if an experimenter has six whole plots (samples) that can each be divided into four sub-plot plots (smaller samples) available for an experiment. To have an efficient estimation of random effects of whole-plot factor (varieties of wheat) and fixed effect of the sub-plot factor (judges)., he should allocate two samples each into three randomly selected varieties of wheat $(v=3, r=2)$. In the same vein, if he has available twelve whole plot that can each be divided into two sub-plot plots (smaller samples) available for an experiment. To have an efficient estimate of random effects of whole-plot factor (varieties of wheat) and fixed effect of the sub-plot factor (judges)., he should allocate two samples each into six randomly selected varieties of wheat $(v=6, r=2)$.

\section{Summary and Conclusions}

This study investigates design preference in Completely Randomized (CR) split-plot experiments involving random whole-plot factor and fixed sub-plot factor. Split-plot experiments are generally named according to the design used at the first stage of randomization. In this work, a completely randomized design was used at the first stage of randomization. The main problem studied is on the optimal structure of the completely randomized design used at the whole-plot stage. The fisher-information matrices of the Maximum Likelihood estimators of the parameters of the model were derived. The criterion for optimality is the design that maximizes the determinant of the product of two information matrices corresponding to the random and fixed part of the model. Comparisons was done using sixteen vectors of values of variance components where the factor variances are larger than the error variances. The sixteen vectors were selected carefully in an attempt to show the robustness of the D-optimal design to different prior proportional values of variances. The results show that designs in which the size of the whole-plot factor is larger than size of replication are D-optimal designs for all the sixteen vectors used. This suggest that when factor variances are larger than the error variances, D-optimal designs are not affected by changes in the prior proportional values of variances. However, each experimenter can specify prior proportional values of the four variances based on the available information. It was also observed from that the choice of the sizes of the sub-plot factor does not affect the structure of the completely randomized design at the whole plot stage. This work can be extended to the unbalanced data case and other forms of split-plot design for balanced and unbalanced data

\section{References}

Anderson, R. L., \& Crump, P. P. (1967). Comparisons of designs and estimation procedures for estimating parameters in two stage nested process. Technometrics, 9, 499-516.

Bingham, D. R., \& Sitter, R. R. (2001). Design Issues in Fractional Factorial Split-Plot Experiments. Journal of Quality 
Technology, 33, 2-15.

Bingham, D. R., \& Sitter, R. R. (2001). Design Issues in Fractional Factorial Split-Plot Experiments. Journal of Quality Technology, 33, 2-15.

Cornell, J. A. (1988). Analyzing data from mixture experiments containing process variable: A split-plot approach. Journal of Quality Technology, 20, 2-23

Crump, P. P. (1954). Optimal Designs to Estimate the Parameters of a Variance Components Model. PhD dissertation, North Carolina State University, Raleigh, NC.

Delgado, J., \& Iyer, H. (1999). Search for optimal designs in a three-stage nested random model. Statistics and Computing, 9, 187-193.

Fedorov, V. V. (1972). Theory of Optimal Experiments. NewYork, USA. Academic Press.

Gaylor, D. W. (1960). The construcution and evaluation of some designs for Estimation of parameters in random Models. PhD dissertation, Institute of Statistics, North Carolina University.

Giovagnoli, A., \& Sebastiani, P. (1989). Experimental design for mean and variance estimation in variance component models. Computational Statistics. Data Analysis, 8, 21-28.

Giovagnoli, A., \& Sebastiani, P. (1990). Erratum to experimental designs for mean and variance estimation in variance component models. Computational Statistics and Data Analysis, 10, 93.

Goos, P., \& Donev, A. (2007). Tailor-made split-plot designs for mixture and process variables. Journal of Quality Technology, 39, 326-339.

Goos, P., \& Vandebroek, M. (2001). Optimal Split-Plot Designs. Journal of Quality Technology, 33, 436-450.

Goos, P., \& Vandebroek, M. (2003). D-optimal split-plot designs with given numbers and sizes of whole plots. Technometrics, 45, 235-245.

Herrendörfer, G. (1979). Optimum designs for estimating the variance components in a simple variance component model (model II), I. Biometrical Journal, 21(1), 11-16.

Khuri, A. I. (2000). Designs for variance components estimation, International Statistica Review, 68, 311-322.

Letsinger, J. D., Myers, R. H., \& Lentner, M. (1996). Response surface methods for bi-randomization structures. Journal of Quality Technology, 28, 381-397

Loeza, S., \& Donev, A. N. (2014). Construction of experimental design to estimate variance components. Computational Statistics and Data Analysis, 71, 1168-1177.

Mukerjee, R., \& Huda, S. (1998). Optimal design for the estimation of Variance Components. Biometrika, 75, 75-80

Muse, H. D., \& Anderson, R. L. (1978). Comparisons of Designs to Estimate Variance Components in a Two-way Classification Model. Technometrics, 20, 159-166.

Norell, L. (2006). Optimal designs for maximum likelihood estimators in one-way random Model. U.U.D.M report 2006, 24, Department of Mathematics, Upsalla University.

Nuga, O., Amahia, G. N., \& Salami, F. (2017). Optimal Designs for the Restricted Maximum Likelihood in a Random Split-plot Model. Lithuania Journal of Statistics, 56(1), 64-71.

Nuga, O., Amahia, G. N., \& Aderogba, F. (2014). Construction of split plot design for estimating variance components. European Scientific Journal, 18, 40-418

Searle, S. R., Casella, G., \& McCulloch, C. E. (1992). Variance Components. New York: Wiley,

Stone, H., \& Sidel, J. L. (2004). Sensory Evaluation Practices. (3rd ed). Elsevier Academic Press, London.

Thompson, W. O., \& Anderson, R. L. (1975). A comparison of Designs and Estimators for the Two-stage Nested Random Model. Technometrics, 17, 37-44

Trinca, L. A., \& Gilmour, S. G. (2001). Multi-stratum response surface designs. Technometrics, 43, $25-33$.

\section{Copyrights}

Copyright for this article is retained by the author(s), with first publication rights granted to the journal.

This is an open-access article distributed under the terms and conditions of the Creative Commons Attribution license (http://creativecommons.org/licenses/by/4.0/). 